\title{
NOTES ON BRYOTHINUSA WITH DESCRIPTION OF THE LARVA OF B. CATALINAE CASEY (COLEOPTERA: STAPHYLINIDAE)*
}

\author{
BY IAN MOORE AND R. E. ORTH \\ Division of Biological Control, University of California \\ Riverside, 92521
}

A number of insects are restricted to special marine habitats along the California seashore. At least one of these habitats is intertidal in the sense that its fauna is regularly submerged by the tides. This is the fauna of the reefs. Several species of staphylinids are known from this region. Members of the staphylinid genera Liparocephalus, Amblopusa and Diaulota are found on the rocky shores of northern California; while in southern California only members of the genera Diaulota and Bryothinusa are known. Several studies have dealt with these insects including Chamberlain and Ferris (1929) and Moore (1956a, 1956b). Larvae of some of the species have been described. The larva of Bryothinusa catalinae Casey is described and illustrated for the first time in this paper.

Bryothinusa catalinae (Fig. 1), the type species of the genus, was described by Casey in 1904. Sawada $(1955,1971)$ described four species from Japan under the name Halaesthenus. Several species were described from the harbor at Hong Kong by Moore and Legner (1971) and Moore, Legner and Chan (1973). Finally, another species was made known by Moore and Legner (1975) from the Gulf of California, bringing the total number of known species to eleven. All but one of these is restricted to an intertidal habitat; the exception being $B$. fluenta Moore et al. which was found by TaiDin Chan in a strictly fresh water habitat in a stream emptying into Hong Kong harbor.

Bryothinusa catalinae is not common in collections probably because of its restricted habitat. Derham Giuliani collected ten adult specimens of this species incidental to other work in October, 1976, near White Point, San Pedro, California, and presented the specimens to us. We made two trips to the area in November and December, 1977, where we found both adults and larvae fairly common. This special habitat may be described as follows:

*Manuscript received by the editor September 15, 1978. 


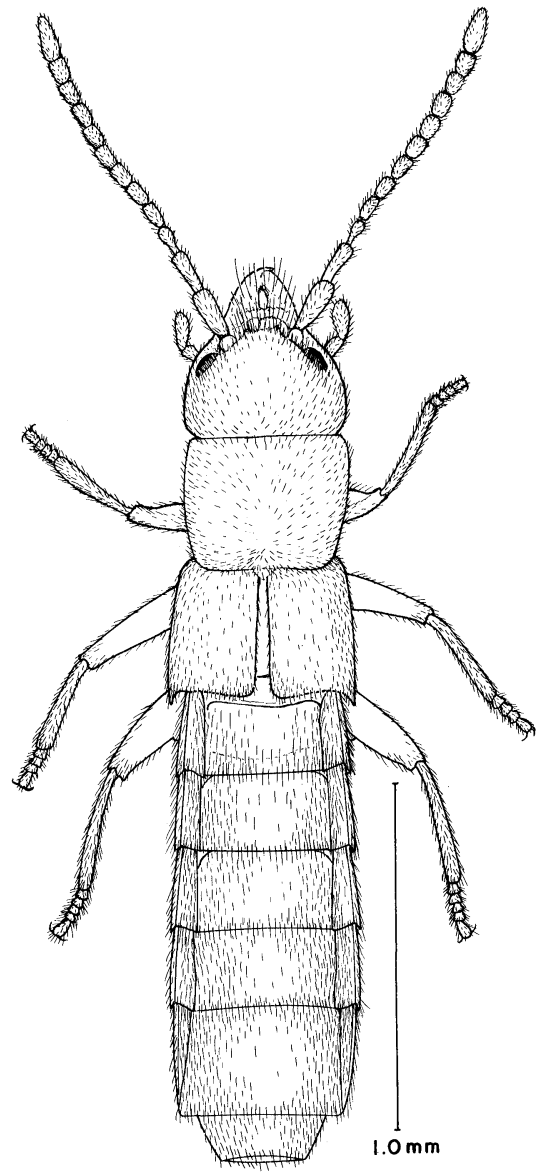

1

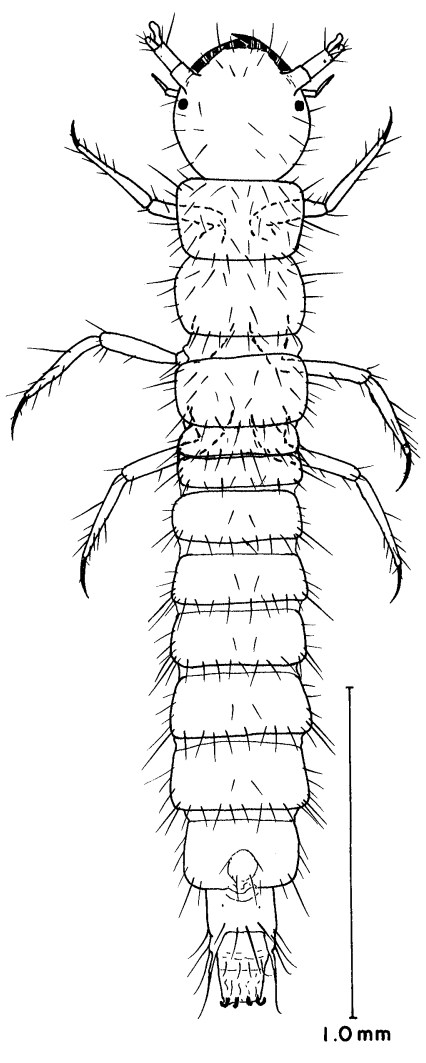

2

Figures 1-2. Bryothinusa catalinae Casey. Fig. 1, Habitus of imago; California, Los Angeles Co., White Point, Dec. 6, 1977, R. E. Orth. Fig. 2, Habitus of larva; same locality data as imago. 
White Point City Park, San Pedro, Los Angeles, California (Fig. 9, photograph), occupies approximately a mile of a narrow strip of cliff and rocky beach along the Pacific Ocean just a few miles north of Point Firmin. Access to the beach is by a steep road down the cliff which joins a road along the beach. The beach area consists of four rocky embayments between five short points. The second embayment from the south is somewhat protected from the open ocean by a 6 foot to 10 foot high ledge along the seaward side of which is the ruin of a concrete wall. Between the concrete wall and the road at the base of the cliff is a shallow reef which is exposed at low-water and under water at high tide. The area is largely a field of boulders two or three feet across with smaller stones and gravel in sand. The staphylinids and their larvae were found beneath and on the stones in an association with dense worm tubes, chitons, limpets, small abalones, flat worms, small crabs and brittle stars. They were most readily collected by a flotation method in which stones were agitated in a bucket of seawater. The insects floated to the surface where they were lifted with a camel's hair brush and transferred to a vial of alcohol. Collecting in the intertidal zone is best done in the fall and winter when low tides occur during daylight.

\section{The larva of Bryothinusa catalinae Casey}

(Fig. 2)

Color. Semitransparent-white except the apices of the mouthparts and the larger setae which are nebulously brown, and black eye-spots on the head.

Head round, widest just behind the eye-spots, neck absent. Ocelli apparently absent. With an ovoid heavily pigmented eye spot on each side near the base of the antenna. Clypeal margin (Fig. 6) with four small teeth. Antenna three-segmented (Fig. 5); first segment wider than long; second segment about as wide as first, almost twice as long as wide, apex with two articulated processes, each about one-third as wide as apex of second segment; one process an "acornlike seta", bears no seta on its surface, is almost twice as long as the other and is somewhat sinuate; the other process which is the actual third antennal segment, bears several ordinary setae and is about twice as long as wide. Maxilla (Fig. 7) with the stipes longer than the palpus, outer half of inner margin with closely placed short teeth. Maxillary palpus three-segmented; first segment about as long as 

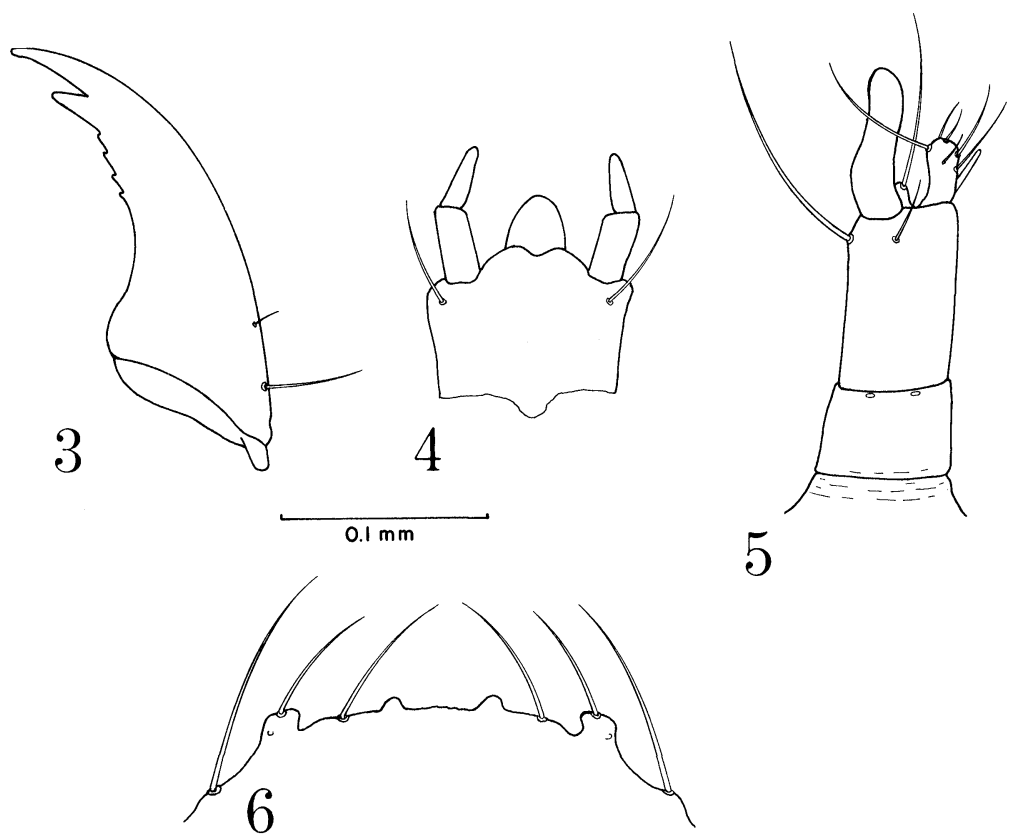

5
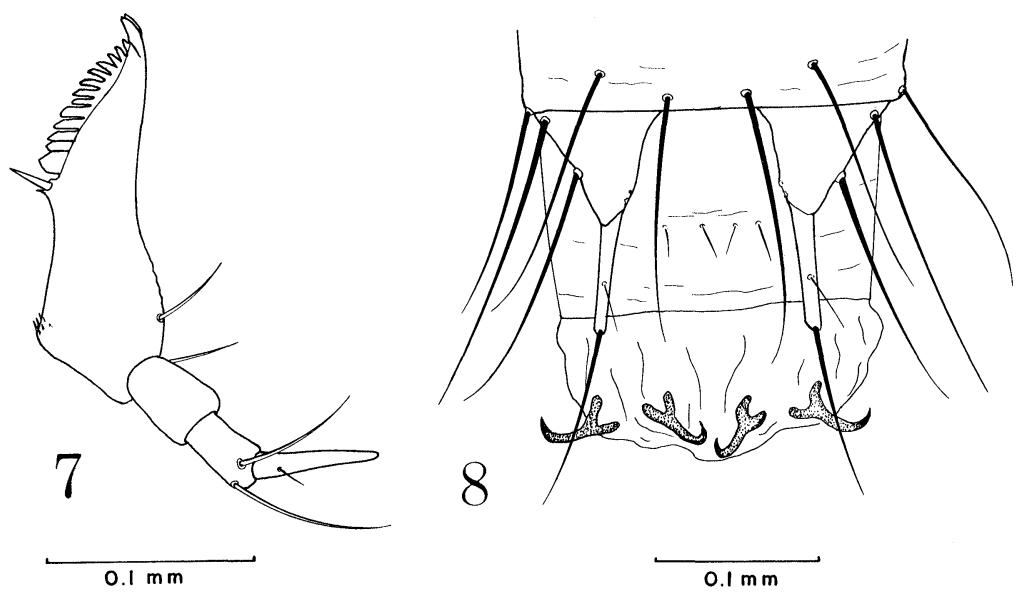

Figures 3-8 Larva of Bryothinusa catalinae Casey. Fig. 3, left mandible; Fig. 4, labium; Fig. 5, right antenna; Fig. 6, anterior margin of clypeus; Fig. 7, right maxilla; Fig. 8, urogomphi and pseudopod. 
wide; second segment somewhat narrower and almost as long as first; third segment narrower and longer than second, tapered to bluntly pointed apex. Mandible (Fig. 3) curved, pointed, with a large internal apical tooth followed by four blunt denticles in the apical half. Ligula (Fig. 4) rounded at apex, about as long as wide, about as long as first segment of labial palpus. Labial palpus (Fig. 4) two-segmented, segments longer than wide, second segment a little narrower than first, tapered to bluntly pointed apex. Gular sutures most approximate in the middle, widely divergent ahead and behind.

Thorax. - Pronotum almost twice as wide as long, apical margin straight, sides gently arcuate, base straight, angles narrowly rounded, with a few scattered setae. Mesonotum and metanotum very similar to pronotum.

Abdomen with the first six segments nearly parallel sided, seventh segment narrower than sixth, eighth segment narrower than seventh. First six segments with two discal setae, a row of about eight setae along the basal margin and scattered setae at the sides. Eighth segment with distinct raised opercula for an osmeterium, the area

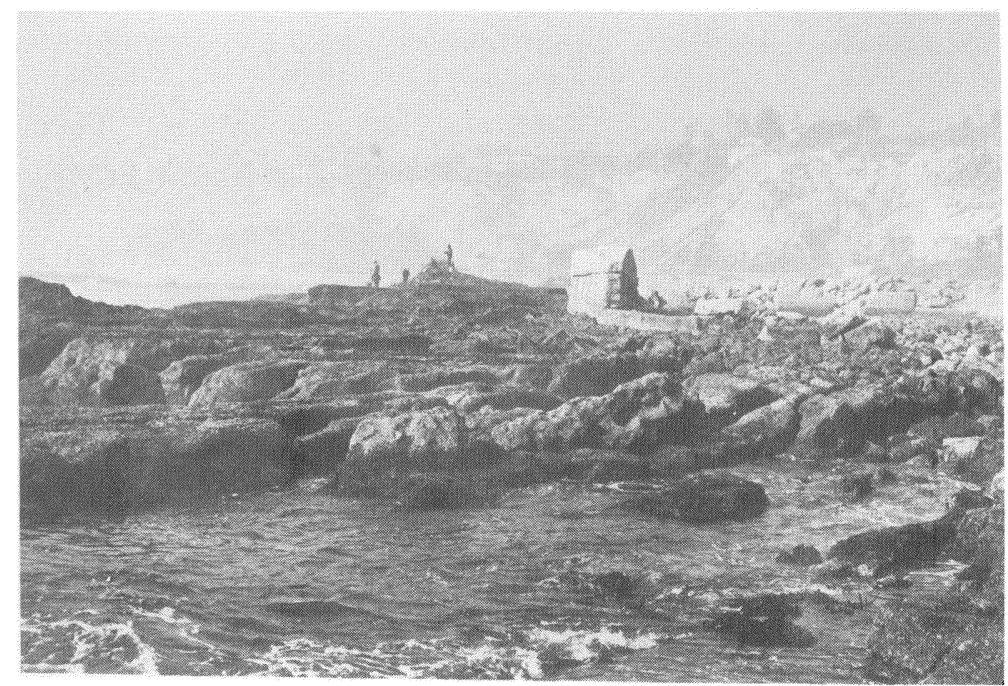

Figure 9. Low tide at White Point City Park, Los Angeles County, California, habitat of Brythinusa catalinae Casey. 
not pigmented. Urogomphus (Fig. 8) two-segmented, first segment broadly triangular, second segment slender, nearly cylindrical, about as long as the first segment. Membrane of apex of pseudopod (Fig. 8) with four small dark hooks, each with a bifid base.

Length $3.0 \mathrm{~mm}$.

Material examined. Two specimens 9 November 1977 and three specimens 6 December 1977, White Point, San Pedro, Los Angeles, California, associated with numerous adults under stones in coarse sand and gravel on the seashore at about the 1 or 2 foot tide level collected by R. E. Orth. In company with these specimens were adults of Diaulota harteri Moore, the only other staphylinid genus known from this habitat.

Notes. The larvae of Bryothinusa can be distinguished from those of Diaulota, the only other staphylinid genus known from this habitat in southern California, by the presence of four small chitinized pigmented hooks with a bifid base imbedded in the apical membrane of the pseudopod. Specimens of larvae examined by us associated with adults of $B$. sawadai Moore et al., B. Hongkongensis Moore et al., B. sinensis Moore et al. and B. chani Moore and Legner all have pseudopodal hooks. Similar pseudopodal hooks have been reported in the larvae of Alianta incana Erickson by Paulian (1941). Paulian's illustrations indicate they may be present in other genera.

\section{Literature Cited}

CAsey, T. L.

1904. On some new Coleoptera including four new genera. Can. Ent. 36: 312-324.

Chamberlain, J. C. and G. F. Ferris

1929. On Liparocephalus and allied genera (Coleoptera: Staphylinidae). PanPac. Ent. 5: 137-143, 153-162, illus.

MOORE, IAN

1956a. A revision of the Pacific Coast Phytosi wirh a review of the foreign genera (Coloptera: Staphylinidae) Trans. San Diego Soc. Nat. Hist. 12: 103-152, illus.

1956b. Notes on some intertidal Coleoptera with descriptions of the early stages (Carabidae, Staphylinidae, Malachiidae). Trans. San Diego Soc. Nat. Hist. 12: 207-230, illus.

Moore, IAN AND E. F. LEgNer

1971. Bryothinusa chani, a new species of marine beetle from Hong Kong (Coleoptera: Staphylinidae). Coleopt. Bull. 25: 107-108. 
1975. A study of Bryothinusa (Coleoptera: Staphylinidae), comparing a tabular key and a dichotomous key to the species. Bull. So. Cal. Acad. Sci. 74: 109-112, illus.

Moore, IAN, E. F. Legner and T. Chan

1973. A review of the genus Bryothinusa with descriptions of three new species (Coleoptera: Staphylinidae). Ent. News 84: 73-81, illus.

Paulian, Renaud

1941. Les premier états des Staphylinoidea. Études de morphologie comparée. Mem. Mus. Nat. Hist. Natur. Paris, n. ser. 15: 1-361, illus.

SAWADA, K.

1955. Marine insects of the Tokara Islands. VIII. Family Staphylinidae (Coleoptera). Publ. Seto Marine Biol. Lab. 5: 81-87, illus.

1971. Aleocharinae (Staphylinidae, Coleoptera) from the intertidal zone of Japan. Publ. Seto Marine Biol. Lab. 19: 81-109. 

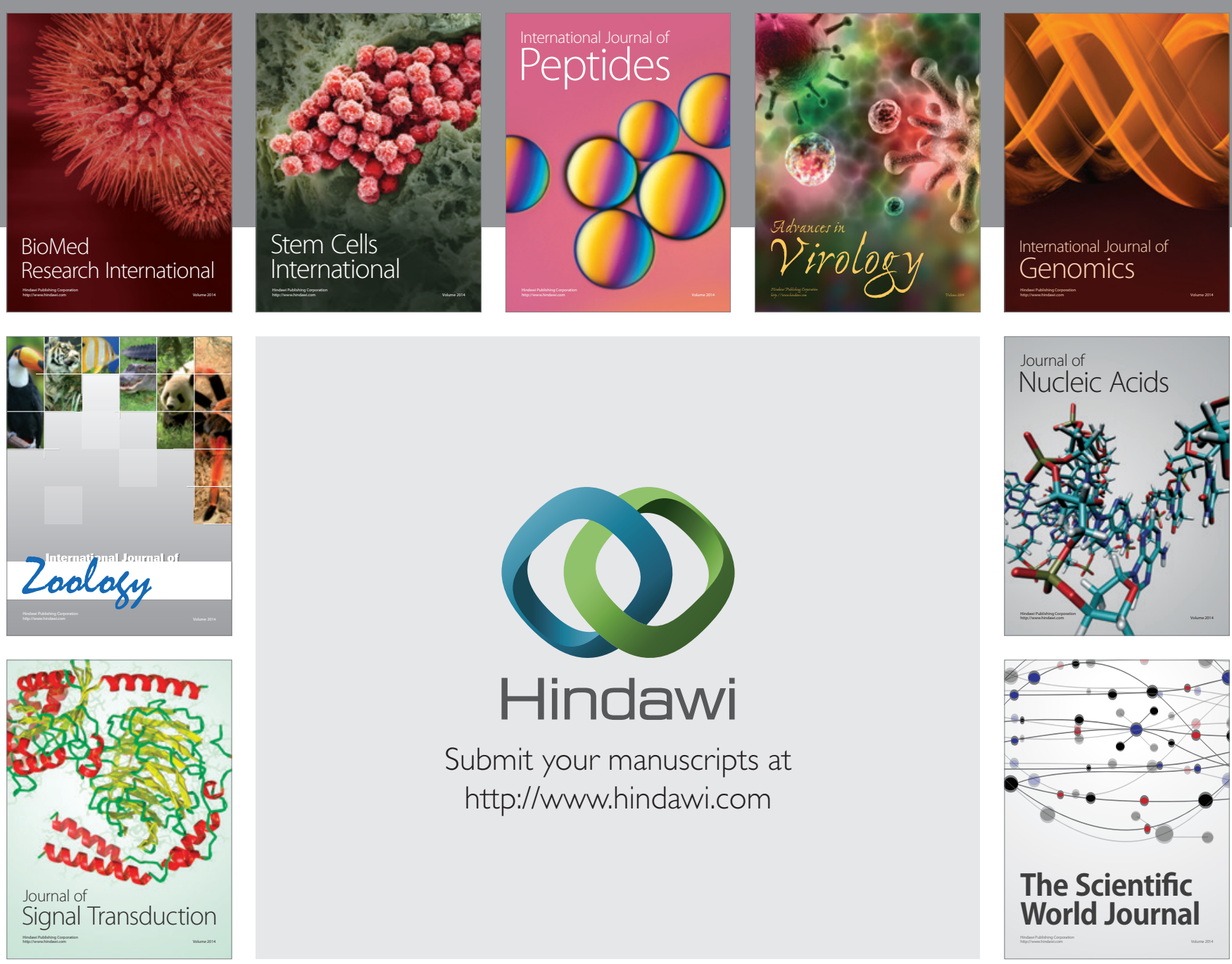

Submit your manuscripts at

http://www.hindawi.com
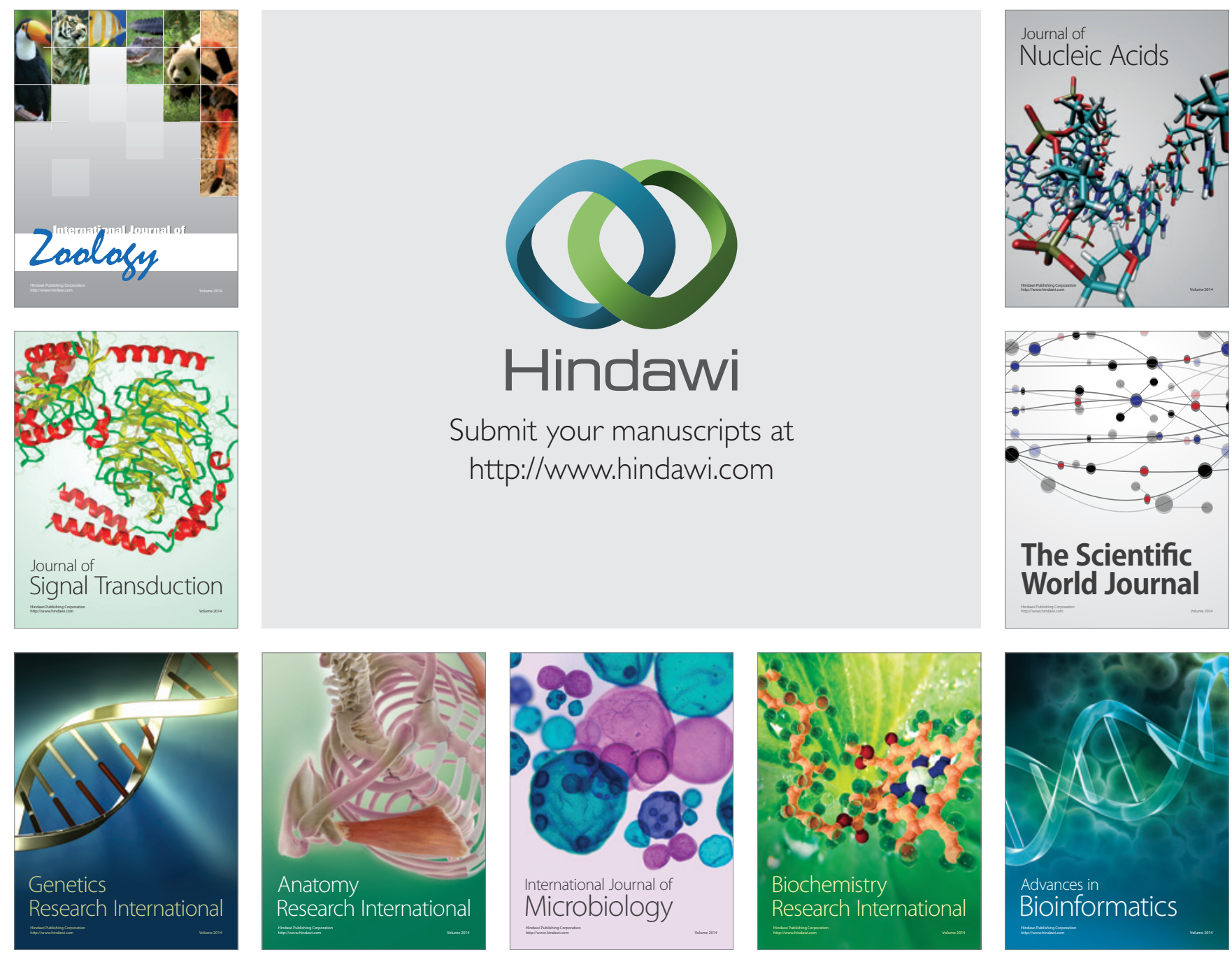

The Scientific World Journal
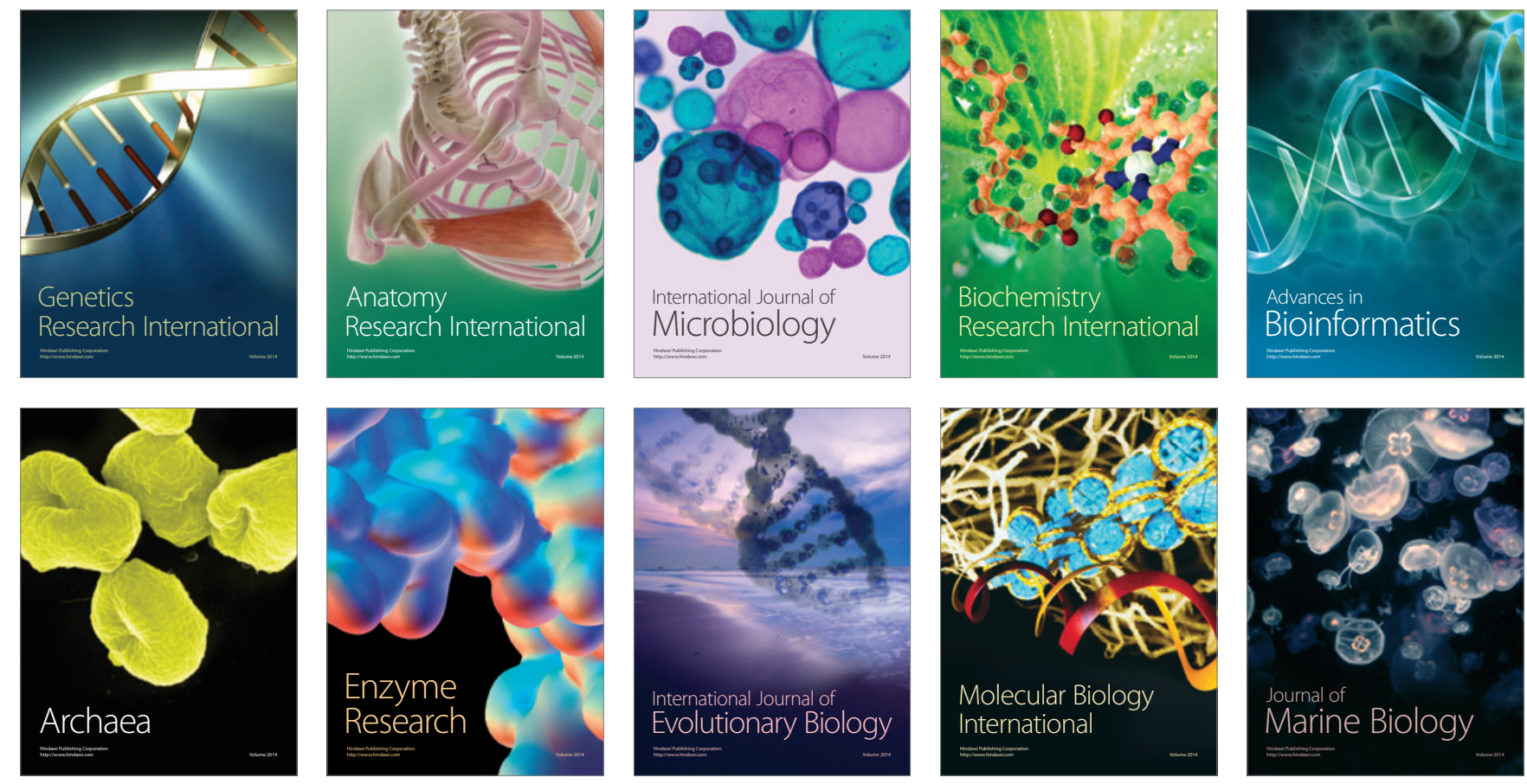